\title{
Otoliths in situ from Sarmatian (Middle Miocene) fishes of the Paratethys. Part I: Atherina suchovi Switchenska, 1973
}

\author{
Werner Schwarzhans ${ }^{1} \cdot$ Giorgio Carnevale $^{2} \cdot$ Alexandre F. Bannikov $^{3} \cdot$ \\ Sanja Japundžic ${ }^{4} \cdot$ Katarina Bradić $^{5}$
}

Received: 4 September 2015/Accepted: 18 November 2015/Published online: 18 January 2016

(C) The Author(s) 2016. This article is published with open access at Springerlink.com

\begin{abstract}
Several well-preserved otoliths were extracted from four slabs containing fish specimens of Atherina suchovi. Atherina suchovi is one of the five Atherina species recorded from the Middle Miocene of the Central and Eastern Paratethys established on articulated skeletal remains. This corresponds to two otolith-based species so far identified from the same time interval in the Paratethys-Atherina austriaca and Atherina gidjakensis. Our correlation of isolated otoliths and otolith in situ documents in this case that $A$. suchovi is not synonymous to any of the otolith-based species, although it appears to be closely related to A. gidjakensis. A list is presented and briefly discussed showing Sarmatian skeleton-based fish records from the Central and Eastern Paratethys with an overview of known and currently studied fishes with otoliths in situ.
\end{abstract}

Keywords Ichthyology $\cdot$ Teleost $\cdot$ Atherinidae ·

Paleontology $\cdot$ Moldavia

Werner Schwarzhans

wwschwarz@aol.com

1 Natural History Museum of Denmark, Zoological Museum, Universitetsparken 15, 2100 Copenhagen, Denmark

2 Dipartimento di Scienze della Terra, Università degli Studi di Torino, via Valperga Caluso 35, 10125 Turin, Italy

3 Borisyak Paleontological Institute of the Russian Academy of Sciences, Profsoyuznaya 123, 117997 Moscow, Russia

4 Department of Geology and Paleontology, Croatian Natural History Museum, Demetrova 1, HR-10000 Zagreb, Croatia

5 Department of Paleontology, Faculty of Mining and Geology, University of Belgrade, Kamenička 6, RS-11000 Belgrade, Serbia

\section{Introduction}

About 60 fossil fish specimens with otoliths in situ have been studied from Sarmatian strata of the collections of the Croatian Natural History Museum, Zagreb (CNHM), Serbian Natural History Museum, Belgrad (NHMB), the Faculty of Mining and Geology of the University of Belgrade (IGOT) and the Borisyak Paleontological Institute of the Russian Academy of Sciences, Moscow (PIN) representing 20 nominal fish species and bringing the total number of Paratethyan fishes with otoliths in situ to 30 nominal species. These will be described in a sequence of research papers, of which this is the first one, and when finalized will represent the largest fossil fish assemblage with otoliths in situ known to date. This first part is dealing with Atherina suchovi. A certain part of the article is constructed to serve as an overall introduction for all following parts to set the scene and reduce unnecessary redundancy.

Several of the specimens studied represent holotypes, lectotypes, paratypes, paralectotypes or syntypes, but many others are not type-specimens of any kind and, therefore, their taxonomic allocation will be reviewed in the course of the study where appropriate. The specimens studied from the Borisyak Paleontological Institute of the Russian Academy of Sciences, Moscow were identified by Bannikov or Baykina; the material housed in the Croatian Natural History Museum mostly belongs to the collection "Sarmatian fishes of Croatia and Slavonia" described by Dragutin Gorjanović-Kramberger and includes either typespecimens of some kind or can be related to relevant typespecimens; the Andjelković collection in the Serbian Natural History Museum and the University of Belgrade is more problematic since they contain few type-specimens and many of the identifications are in need of revision. 
Otoliths in situ in fossil fish are very important for paleoichthyological studies, because they provide a crucial evidence for potential parallel taxonomy (Bachmayer and Weinfurter 1965; Bedini et al. 1986; Fedotov 1971; Gaudant and Reichenbacher 2005; Schwarzhans 2014), as well as a remarkable opportunity in otolith research to calibrate fossil findings with coeval data derived from articulated skeletons, while otherwise systematic allocation of isolated fossil otoliths is restricted to comparison with extant otoliths only. Fossil fish skeletons of teleosts with otoliths in situ have traditionally been regarded to be rather rare. In 1985, Nolf listed not more than 45 species of fossil fishes recorded with otoliths in situ, and considered only 23 of them to have otoliths "well enough preserved or suitable oriented to show taxonomically useful features'. In Nolf (2013), the list was expanded to 96 fish species with otoliths recorded in situ, of which 45 were considered as taxonomically 'useful'. The scarcity of fossil otoliths in situ, however, has never been exhaustively explained or challenged, even though it is evident that otoliths, which consist of aragonite are much easier dissolved during rock diagenesis or exposure compared with bones, scales and teeth. Our ongoing study, of which this is the first part, will demonstrate that fossil otoliths in situ may in fact be more common than commonly perceived and hopefully contribute to more research work in this field.

In a study dealing with otoliths in situ of the gadid Palimphemus anceps Kner 1862, Schwarzhans (2014) reminded about a publication by Schubert (1906), who mentioned 10 species from the Sarmatian of Dolje near Zagreb in which he had observed otoliths in situ. Tragically, the untimely death of Schubert, who perished during World War I, prevented him to work on that material. In 2010, Bannikov noted in passing that fishes from the Sarmatian of Russia and Moldavia, i.e., Eastern Paratethys almost always contain otoliths in situ, and in fact described himself a few such species-Morone ionkoi Bannikov 1993; Symphodus salvus Bannikov 1986; Clinitrachoides gratus (Bannikov 1989). The description of a sparid fish (Pshekharus yesinorum Bannikov and Kotlyar 2015) with otoliths in situ was in press by Bannikov and Kotlyar during the time of manuscript submission. Other otoliths in situ previously described from Badenian and/or Konkian-Sarmatian fishes of the Central and Eastern Paratethys were reported in Bregmaceros albyi (Sauvage, 1880) (in Bachmayer and Weinfurter 1965), Micromesistius sp. (Carnevale et al. 2006), Palimphemus anceps Kner 1862 (in Schwarzhans 2014), Paratrisopterus avus Fedotov 1971 (in Fedotov 1976), Sparus insignis (Prochazka 1893) (in Brzobohaty 1979), Protonymus gontsharovae Sytchevskaya and Prokofiev 2007 (in Sytchevskaya and Prokofiev 2007) and Gobius elatus Steindachner 1860 (in Schultz 2013). We took up these valuable reports to systematically search for otoliths in situ of Sarmatian fishes primarily from the collection of "Sarmatian fishes of Croatia and Slavonia" described by Dragutin Gorjanović-Kramberger from Dolje near Zagreb housed in the Croatian Natural History Museum in Zagreb, the collection assembled by Jelena S. Andjelković from excavations at the Belgrad football stadium and housed in the Serbian Natural History Museum and the University, Belgrad, and from the collection of the Borisyak Paleontological Institute of the Russian Academy of Sciences, Moscow in large part collected by Alexandre F. Bannikov.

Table 1 summarizes the teleost species recorded from the Sarmatian (and Konkian) described from the Central Paratethys based on Andjelković (1989), Baciu et al. (2005) and Schultz (2013) and the Eastern Paratethys based on Carnevale et al. (2006), Bannikov (2010) and Baykina (2012, 2015). We consider the taxonomic status of the fishes from the Eastern Paratethys as modern and adequate, but the taxonomic status of the fishes from the Central Paratethys is in urgent need of review. For instance, one might readily conclude that the number of species in clupeids or gadids in the Central Paratethys could be exaggerated and that the occurrence of Mediterranean species in the isolated Middle Miocene Paratethys appears unlikely. However, it is not our target to perform a taxonomic review of the fishes concerned, except when otoliths and fishes with otoliths in situ provide for new insights. The purpose of our study is to adequately document the data, with focus on the otoliths in situ, and align skeletal and otolith-based identifications wherever possible to provide the basis for calibrating the fossil otolith record.

\section{Materials and methods}

Among the type series of A. suchovi (Switchenska 1973) housed in the PIN collection, there are 10 complete specimens with otoliths in situ. Subsequent recent excavations of A. F. B. at the type locality yielded numerous complete and incomplete skeletons of $A$. suchovi (PIN collection, uncatalogized), a number of which also have the otoliths in situ. Of them, the four fish skeletons of $A$. suchovi with otoliths in situ described here are now housed at the Geological Museum of the Natural History Museum of Denmark in Copenhagen (GMUH). Comparative otolith material studied: six specimens of Atherina gidjakensis from the Konkian of Mangyshlak, Kazakhstan, housed at the Natural History Museum of Ukraine in Kiev (NMNH) as published by Bratishko et al. (2015) and three specimens of Atherina austriaca from the Serravallian of the Karaman Basin, SE-Turkey, from the collection of Schwarzhans.

The otolith-bearing specimens of A. suchovi studied here are incomplete, but stem from the same location 
Table 1 List of nominal skeleton-based teleost species in the Central and Eastern Paratethys during Sarmatian, Konkian and Karaganian and middle to late Badenian, respectively

Central Paratethys $\quad$ Eastern Paratethys

Clupeidae

Alosa crassa Sauvage 1873*

Alosa elongata Agassiz 1842*

Alosa aff. nordmani Antipa 1906*

Alosa pinarhisarensis Rückert-Ülkümen 1965*

Alosa sculptata Weiler 1928

Clupea arcuata Kner 1863

Clupea elongata Steindachner 1860

Clupea gorjensis Huica and Gheorghiu 1962

Clupea heterocerca Kramberger 1883

Clupea humilis H.v.Meyer 1851*

Clupea inflata Vukotinovic 1870

Clupea intermedia Kramberger 1885

Clupea lanceolata H.v.Meyer 1852*

Clupea maceki Kramberger 1883

Clupea melettaeformis Steindachner 1860

Clupea sarmatica Böhm 1929

Clupea sphaerocephala Vukotinovic 1870

Clupea spinosa Rückert-Ülkümen 1965*

Clupea voinovi Pauca 1929

Etrumeus boulei Arambourg 1927*

Sardinella beogradensis Andjelkovic 1967

Sardinella sardinites (Heckel 1850)*

Sarmatella doljeana (Kramberger 1883)

Sarmatella vukotinovici (Kramberger 1883)

Stolephorus lemoinei (Arambourg 1927)*

Myctophidae

Myctophum columnae (Sauvage 1873)*

Salmonidae

Salmo ? immigratus Kramberger 1891

Belonidae

Belone tenuis Kramberger 1898

Bregmacerotidae

Bregmaceros albyi (Sauvage 1880)*,a

Gadidae

Brosmius elongatus Kramberger 1883

Brosmius fuchsianus Kramberger 1883

Brosmius murdjadjensis Arambourg 1927*

Brosmius longipinnatus (Kramberger 1880)

Brosmius strossmayeri Kramberger 1883

Brosmius susedanus Kner 1863

Gadus aeglefinoides (Kner and Steindachner 1863)

Gadus extensus (Kramberger 1891)
Clupea stauropolitana Bogatchov 1933

Clupea humilis H.v.Meyer 1851*

Clupea lanceolata H.v.Meyer 1852*

Sardina tarletskovi Baykina 2015

Sardinella perrata Daniltchenko 1970

Sardinella sardinites (Heckel 1850)*

Sarmatella pshekhensis (Baykina 2012)

Sarmatella tsurevica (Baykina 2012)** 
Table 1 continued

\author{
Central Paratethys \\ Gadus lanceolatus (Kramberger 1883) \\ Gadus macropterygius (Kramberger 1883) \\ Gadus minimus (Kramberger 1885) \\ Gadus szagadatensis (Steindachner 1863) \\ Palimphemus anceps Kner $1862^{\mathrm{C}}$ \\ Syngnathidae \\ Syngnathus affinis Kramberger 1891 \\ Syngnathus albyi Sauvage 1817* \\ Syngnathus helmsii Steindachner 1860 \\ Holocentridae \\ Holocentroides moldavicus Pauca 1931 \\ Mugilidae
}

Mugil radobojanus Kramberger 1882

Atherinidae

Atherina sarmatica Kramberger 1891

Sphyraenidae

Sphyraena croatica Kramberger 1882

Scorpaenidae

Scorpaena jeanneli Arambourg 1927*

Scorpaena minima Kramberger 1882

Scorpaena pilari Kramberger 1882

Mullidae

Mullus gorjanovici Andjelkovic 1969

Serranidae

Properca sabbai Pauca 1929*

Serranus altus Kramberger 1882

Serranus dubius Kramberger 1882

Moronidae

Morone intermedia Kramberger 1882

Morone neumayri (Kramberger 1882)

Latidae

Lates croaticus Kramberger 1902
Eastern Paratethys

Gadus macropterygius (Kramberger 1883)

\section{Micromesistius sp. $^{\mathrm{b}}$}

Paratrisopterus avus Fedotov $1971^{\mathrm{d}}$

Paratrisopterus caspius (Bogatchov 1929)

Paratrisopterus kiplingi (Bogatchov 1929)

Syngnathid indet

Mugil acer Switchenska 1959

Mugil finitimus Switchenska, 1973

Mugil karaganicus Switchenska 1973

Mugil minax Bogatshov 1933

Atherina impropria Switchenska 1973

Atherina prima Switchenska 1959

Atherina schelkovnikovi Bogatshov 1936

Atherina suchovi Switchenska $1973^{\mathrm{e}}$

Atherina sumgaitica Switchenska 1973

Parasphyraena apsheronica Switchenska 1968

Mullus moldavicus Switchenska 1959

Morone ionkoi Bannikov $1993^{\mathrm{f}}$

Lates gregarius Bannikov 1992 
Table 1 continued

Central Paratethys Eastern Paratethys

Priacanthidae

Priacanthus croaticus (Kramberger 1885)

Carangidae

Caranx haueri Kramberger 1882

Caranx longipinnatus Kramberger 1882

Seriola gracilis Böhm 1942

Centracanthidae

Naslavcea fundata (Bannikov 1990)

Sparidae

Boops roulei Arambourg 1927*

Sparus brusinai (Kramberger 1882)

Sparus insignis (Prochazka 1893) ${ }^{\mathrm{h}}$

Sparus intermedius (Kramberger 1902)

Sciaenidae

Sciaena? multipinnata (Kramberger 1882)

Pomacentridae

Chromis savornini Arambourg 1927*

Polynemidae

Labridae

Polydactylus frivolus Bannikov 1989

Symphodus salvus Bannikov 1986

Symphodus woodwardi (Kramberger 1891)

Scombridae

Auxis croaticus Kramberger 1882

Auxis minor Kramberger 1882

Auxis thynnoides Kramberger 1882

Auxis vrabcensis Kramberger 1882

Scomber priscus Kramberger 1882

Scomber sarmaticus Kramberger 1882

Scomber steindachneri Kramberger 1882

Callionymidae

Callionymus macrocephalus Kramberger 1882

Sciaena knyrkoi Daniltshenko 1980

Sciaena pimenovae Bogatshov 1955

Sparus? brevis (Lednev 1914)

Sparus brusinai (Kramberger 1882)

Scomber caucasicus (Bogatshov 1933)

Callionymus macrocephalus Kramberger 1882

Protonymus gontsharovae Sytchevskaya and Prokofiev $2007^{j}$

Trachinidae

Trachinus dracunculus Heckel 1849

Blenniidae

Blennius fossilis Kramberger 1891

Clinidae

Clinitrachoides gratus (Bannikov 1989) ${ }^{\mathrm{k}}$

Gobiidae

Gobius brivesi Arambourg 1927*

Gobius elatus Steindachner $1860^{1}$ 
Table 1 continued

\begin{tabular}{|c|c|}
\hline Central Paratethys & Eastern Paratethys \\
\hline \multicolumn{2}{|c|}{ Gobius oblongus Steindachner 1860} \\
\hline \multicolumn{2}{|c|}{ Gobius pullus Kramberger 1882} \\
\hline \multicolumn{2}{|c|}{ Gobius viennensis Steindachner 1860} \\
\hline & “Gobius” sp. \\
\hline & Pomatoschistus sp. $^{\text {b }}$ \\
\hline \multicolumn{2}{|l|}{ Caproidae } \\
\hline \multicolumn{2}{|c|}{ Proantigonia octacantha Kramberger 1882} \\
\hline \multicolumn{2}{|c|}{ Proantigonia radobojana Kramberger 1882} \\
\hline & $\begin{array}{l}\text { Proantigonia dagestanica Baciu, Bannikov and Tyler } \\
2005\end{array}$ \\
\hline
\end{tabular}

Bothidae

Arnoglossus ovalis Switchenska 1981

Bothus sp.

Rhombus bassanianus Kramberger 1883

Rhombus parvulus Kramberger 1883

Rhombus serbicus Andjelkovic 1966

Rhombus stamatini Pauca 1931

Pleuronectidae

Platichthys svitschenskajae (Dzhafarova 1976)

Soleidae

Achirus mediterraneus Arambourg 1927*

Microchirus abropteryx (Sauvage 1870)*

Central Paratethys based on Andjelković (1989), Baciu et al. (2005) and Schultz (2013); Eastern Paratethys based on Carnevale et al. (2006), Bannikov (2010), Bannikov and Kotlyar (2015) and Baykina (2012, 2015). The systematic follows Nelson (2006)

Skeletons with otoliths in situ are shown in bold

* Originally described from outside Paratethys and identity of referred fishes in the Paratethys questionable

** Isolated otolith attributed to skeleton-based species based on taxonomic evidence

Superscript alphabets refer to published otoliths in situ: ${ }^{a}$ Bachmayer and Weinfurter (1965) from the lower Badenian of Austria; ${ }^{\mathrm{b}}$ Carnevale et al. (2006) from the Sarmatian of Russia; ${ }^{\mathrm{c}}$ Schwarzhans (2014) from the middle Badenian of Poland; ${ }^{\mathrm{d}}$ Fedotov (1971) from the Sarmatian of Moldavia; ${ }^{\mathrm{e}}$ this paper; ${ }^{\mathrm{f}}$ Bannikov (1993, 2009) from the Sarmatian of Moldavia; ${ }^{\mathrm{g}}$ Bannikov and Kotlyar (2015) from the Sarmatian of Russia; ${ }^{\text {h }}$ Brzobohaty (1979) from the late Badenian of Slovakia (species identified on basis of the otolith in situ) ${ }^{\mathrm{i}}$ Bannikov (1986) from the Sarmatian of Moldavia; ${ }^{j}$ Sytchevskaya and Prokofiev (2007) from the Konkian of Russia; ${ }^{k}$ Bannikov (1989) from the Sarmatian of Moldavia; ${ }^{1}$ according to Schultz (2013) from the Sarmatian of Austria

mentioned above and containing only a single atherinid species (Bannikov 2009). Moreover, the studied otoliths are identical to those of the complete specimens, including those of the type series.

Otoliths were first identified on the skeleton-bearing slabs by visual inspection. When considered well enough preserved they were carefully cleaned trying to keep any damage to fish or otolith at a minimum. Since otoliths are often fragile and rather soft we commonly left them in the rock after having cleaned the surface of its inner face as much as possible. By this, fracturing of the otoliths or severance was kept to a minimum. As a consequence of this procedure, no lateral views of otoliths of $A$. suchovi are produced. In addition, the otolith specimen is maintained associated with the skeleton to reduce the risk of potential future loss or damage or any uncertainty about the corre- 
lation between otolith and articulated skeleton. The morphological terminology of otoliths was established by Koken (1891) with amendments by Weiler (1942) and Schwarzhans (1978). The morphometric measurements of otoliths follow Schwarzhans (2013). Documentation of otoliths is provided by photographs. All otoliths are shown from the right side. Left otoliths are mirror imaged and annotated accordingly ('reversed').

Abbreviations used are: general: institution acronyms see above, $v s$ versus, skeletons: $S L$ standard length, $T L$ total length, $H L$ head length, $D$ dorsal-fin rays (including D1, D2 and D3 as the case may be), $A$ anal fin rays (including A1 and A2 as the case may be), $P$ pectoral fin rays, $V$ pelvic fin rays, $C$ principal caudal fin rays; Roman numerals denote spiny fin rays, Arabic numerals denote branched fin rays; otoliths: $O L$ otolith length, $O H$ otolith height, $O T$ otolith thickness, $S u L$ sulcus length, $O S L$ ostium length, $\mathrm{OsH}$ ostium height, $\mathrm{CaL}$ cauda length, $\mathrm{CaH}$ cauda height.

\section{Systematic paleontology}

Class Osteichthyes Huxley 1880

Division Teleostei Müller 1846

Order Atheriniformes Rosen 1964

Family Atherinidae Risso 1827

Genus Atherina Linnaeus 1758

Atherina suchovi Switchenska 1973

(Figure 1a-d)

1954 Atherina sarmatica Gorjanovic-Kramberger 1891Ionko: pl. 1, Fig. 4.

1973 Atherina suchovi Switchenska-Switchenska: pl. 5,

Figs. 5, 6, pl. 6, Figs. 1-5, pl. 7, Figs. 1-3.

1980 Atherina suchovi Switchenska 1973-Switchenska: pl. 15, Figs. 4-5.

2009 Atherina suchovi Switchenska 1973-Bannikov: pl. 11, Fig. 1

2010 Atherina suchovi Switchenska 1973-Bannikov: pl. 2, Fig. 3

\section{Remark}

The spelling of 'Switchenska' follows the transliteration from the Polish root of the name.

\section{Material}

4 partially complete articulated skeletons with 5 otoliths in situ from Naslavcea, northern Moldavia, Middle Miocene, Serravallian, Early Sarmatian (Volhynian), collected, identified and donated by A. Bannikov, now housed at GMUH VP-9505-9508.

\section{Short description of fish}

Maximum body depth 17-21 \% SL; head length 25-30\% SL. Orbit diameter 32-42\% HL. Premaxillary length exceeds orbit diameter. Ascending premaxillary process longer than alveolar ramus. First dorsal-fin origin placed above the 13 or 14 th vertebra; interdorsal (D1-D2) space equals 5-6 vertebrae. Anal fin inserts in advance of the second dorsal-fin origin by about 2 rays. Preanal length 62-68 \% SL. Vertebrae 39-40 $(18-19+20-22)$. D1 = VI-VII, D2 = I + 10-11; A = I + 12-14.

\section{Description of otoliths in situ (3 specimens measured)}

Moderately elongate otoliths to slightly larger sizes than $1.5 \mathrm{~mm}$ length. $\mathrm{OL}: \mathrm{OH}=1.4-1.5$. Outline: regularly oval without prominent angles and short, but mostly pointed rostrum. Dorsal rim irregularly undulating or crenulated; ventral rim slightly shallower than dorsal rim and very regularly curved, smooth. Posterior rim rounded or blunt, usually pronounced ventral of caudal tip. Excisura and antirostrum weak. Inner face slightly convex with narrow, slightly supramedian and moderately deep sulcus. Cauda moderately narrow, nearly straight, just very slightly bent at termination, which is at moderate distance from posterior tip of otolith. Ostium slightly wider than cauda and short; CaL:OsL $=1.85-2.0$. Dorsal depression long, ventrally marked by well-developed crista superior, dorsal margin indistinct; ventral furrow indistinct. Outer face nearly flat, rather smooth.

\section{Comparison}

Bratishko et al. (2015) listed three fossil otolith-based species of Atherina. One of these, A. austriaca Schubert 1906, ranges from the uppermost Burdigalian (Karpatian) to Serravallian of the Central Paratethys (e.g., Brzobohaty and Stancu 1974; Brzobohaty 1994; Brzobohaty et al. 2003) and the Mediterranean (Schwarzhans 2014), A. gidjakensis (Pobedina 1956) (with A. kalinoraensis Rückert-Ülkümen and Kaya 1993 representing a junior synonym) ranges from the Karaganian to Pannonian of the Eastern Paratethys and is also mentioned from the Pontian of the Vienna Basin (Brzobohaty 1992), and A. mutila Rückert-Ülkümen 1996 is known from the Sarmatian to Pontian of the Thrace Basin. Otoliths of A mutila (not figured herein) can be easily distinguished by their elongate shape $(\mathrm{OL}: \mathrm{OH}=1.8-1.9)$ and very long cauda reaching close to the posterior tip of the otolith. This species may belong to a different atherinid genus.

With respect to the other two species the differences are subtle, but consistent: otoliths of A. austriaca (Fig. 1e, f) 


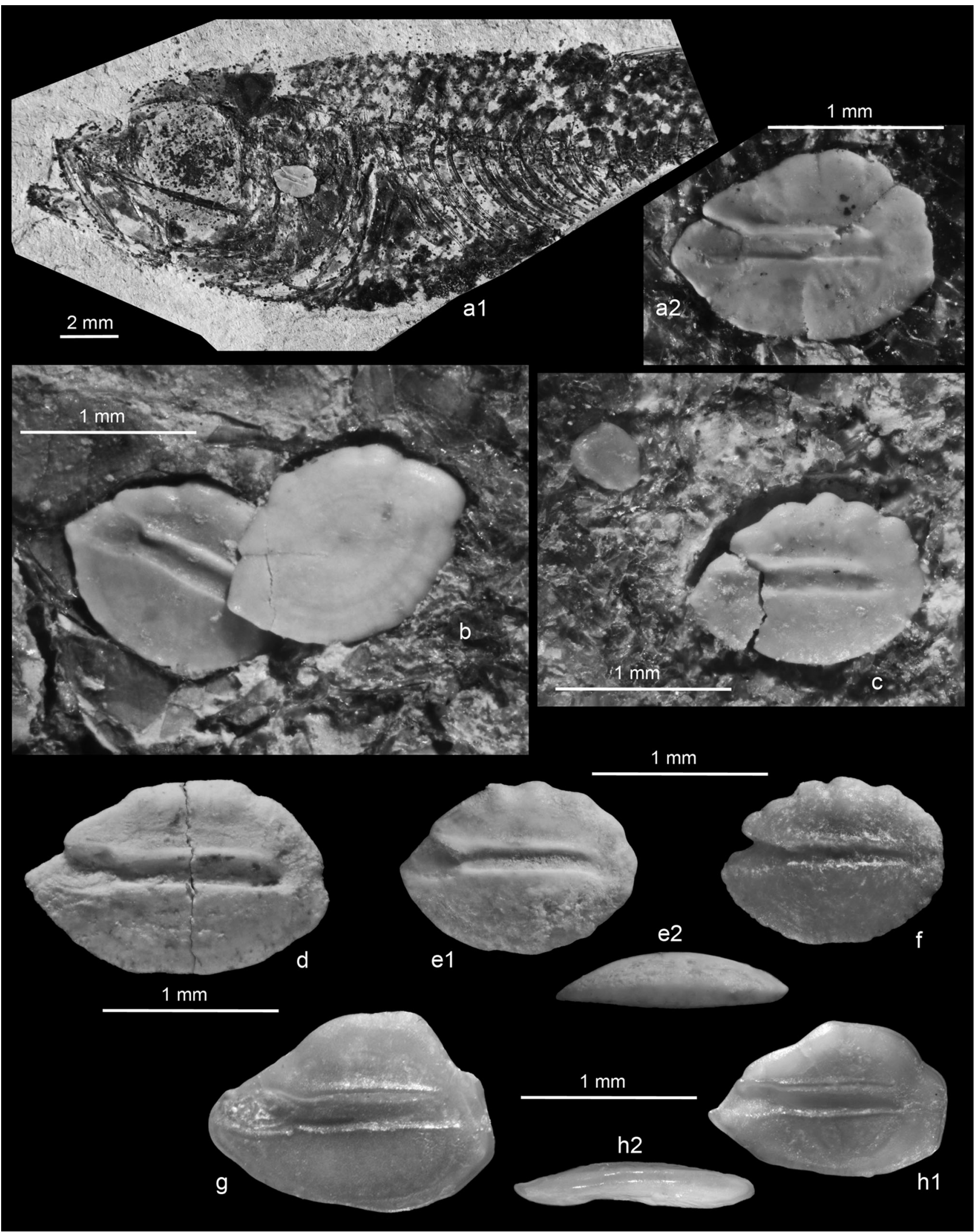


4Fig. 1 Middle Miocene, Serravallian Atherina otoliths from the Mediterranean and the Paratethys. a-d Atherina suchovi Switchenska, 1973, early Sarmatian of Naslavcea, Moldavia. All otoliths are sagittal otoliths and shown from inner face, if not mentioned otherwise. a1 Fish specimen 1 (GMUH VP-9505) with otolith in situ (reversed); $\mathbf{a} 2$ close-up view of otolith of the same specimen (reversed). b Close-up view of fish specimen 2 (GMUH VP-9506) with both sagittal otoliths in situ, upper one shown from the outer face (reversed). c. Close-up view of fish specimen 3 (GMUH VP-9507) showing fractured sagittal otolith and small, triangular lapillus otolith (upper left), both in situ. d Extracted otolith from fish specimen 4 (GMUH VP-9508), fractured during recovery process (reversed). ef Atherina austriaca Schubert, 1906, late Serravallian of Seyithasan, Karaman Basin, Turkey, coll. Schwarzhans (reversed). e2 Ventral view of same otolith as e1. $\mathbf{g}-\mathbf{h}$ Atherina gidjakensis (Pobedina, 1956), Konkian, Karagaily, Mangyshlak, Kazakhstan, NMNH 2532/031 and/034 (reversed; refigured from Bratishko et al. 2015). h2 Ventral view of same otolith as h1

differ from those of $A$. suchovi in being slightly more compressed (OL:OH $=1.3-1.4$ vs $1.4-1.5$ ), more regularly oval in outline with a short rostrum and a continuously crenulated dorsal rim, and a thinner and longer cauda, the latter expressed in a higher ratio CaL: OsL of 2.1-2.4 (vs 1.85-2.0). Moreover, they are thicker and show a more convex inner face. Much more similar to A. suchovi is the coeval A. gidjakensis from the Eastern Paratethys (Fig. 1g, h). Both species share a similar irregularly developed dorsal rim, a rather wide cauda and a mildly convex inner face. Despite the rather strong morphological variability observed in the otoliths of both species, a few consistent differences seem to hold. Otoliths of A. gidjakensis tend to be slightly more elongate than those of $A$. suchovi (OL:OH = 1.45-1.6 vs 1.4-1.5), are characterized by a longer cauda (CaL: OsL $=1.85-2.3$ vs $1.85-2.0$ ) a remarkably strong rostrum, a ventral rim which is deepest well behind its midlength (vs at its midlength) and a coarsely ornamented, but not crenulated dorsal rim with a high, broadly undulating bulge (stronger than the most coarsely ornamented specimen of $A$. suchovi as depicted in Fig. 1a1, a2). These observed subtle differences correlate in character and magnitude to those observed in otoliths of the three extant European species A. boyeri Risso 1810, A. hepsetus Linnaeus, 1758 and A. presbyter Cuvier 1829 as figured by Chaine (1958), Lombarte et al. (2006) and Nolf et al. (2009). We, therefore, conclude that A. gidjakensis and $A$. suchovi are different species.

\section{Discussion}

Carnevale et al. (2011) listed and compared the five known recent species of the genus, all from the Atlantic and Mediterranean and the eight skeleton-based fossil species of the genus. Of the fossil ones, all but one (Atherina cavalloi Gaudant 1979 from the Messinian of the
Mediterranean) have been described from the Paratethys: two from the Karaganian of the Eastern Paratethys (Atherina prima Switchenska 1959 and A. sumgaitica Switchenska 1973), two from the Sarmatian of the Eastern Paratethys (Atherina impropria Switchenska 1973 and A. suchovi Switchenska 1973), one from the Sarmatian of the Central Paratethys (Atherina sarmatica Gorjanovic-Kramberger 1891), and two from the Maeotian and Pontian of the Caspian Basin s.l. (Atherina atropatiensis Carnevale, Haghfarshi, Abbasi, Alimohammadian and Reichenbacher, 2011 and A. schelkovnikovi Bogatshov 1936). In addition, A. colchidica Gabelaia 1971 is known from the Lower Pliocene (?) of Abkhasia. Bannikov (2010) synonymized A. sumgaitica with $A$. prima. It seems logical to expect that any of those three fossil otolith-based Atherina species would correlate with some of the respective skeleton-based species once otoliths in situ have been retrieved. In the case of A. suchovi, however, no such correlation presents itself.

Several other cases of atherinid otoliths in situ have been recorded from species of the fossil genus Hemitrichas Peters 1877 from brackish and freshwater rocks of the Upper Rhine Valley of Germany by Keller et al. (2002) and Gaudant and Reichenbacher (2005) (see also extensive discussion about Hemitrichas in Reichenbacher 2000). Their otoliths are readily distinguished from any of the Atherina otoliths discussed here by their very short rostrum and ostium, the strongly convex inner face and the deep cauda.

Acknowledgments We are very thankful to J. van der Voort (Venne near Osnabrïck) and A. Janssen (Katwijk), who have made available comparative otolith material of A. austriaca and A. Bratishko (Lugansk), who supported with otoliths of A. gidjakensis. We further wish to thank R. Brzobohaty (Brno) and B. Reichenbacher (München) for their suggestions for improvement of an earlier version of the manuscript. The research of GC was supported by grants (ex-60\% 2013 and 2014) from the Università degli Studi di Torino. The research of AFB was supported by the Russian Foundation for Basic Research, Project Nos. 14-04-00005 and 13-04-01202.

Open Access This article is distributed under the terms of the Creative Commons Attribution 4.0 International License (http://crea tivecommons.org/licenses/by/4.0/), which permits unrestricted use, distribution, and reproduction in any medium, provided you give appropriate credit to the original author(s) and the source, provide a link to the Creative Commons license, and indicate if changes were made.

\section{References}

Andjelković, J. (1989). Tertiary fishes of Yugoslavia. Stratigraphicpaleontologic-paleoecological study. Palaeontologia Yugoslavica, 38, 1-121.

Bachmayer, F., \& Weinfurter, E. (1965). Bregmaceros-Skelette (Pisces) mit in situ erhaltenen Otolithen aus den tortonischen Ablagerungen von Walbersdorf, Österreich. Senckenbergiana lethaea, 46a, 19-33. 
Baciu, D.-S., Bannikov, A.F., Tyler, J.C. (2005). Revision of the fossil fishes of the family Caproidae (Acanthomorpha). Micellanea Paleontologica, 8, Studi e recerche sui giacimenti terziari di Bolca xi-Verona, 11, 7-74.

Bannikov, A. F. (1986). The first discovery of fossil wrasses (Teleostei) in the Sarmatian deposits of Moldavia. Paleontological Journal, 20(1), 57-62.

Bannikov, A. F. (1989). The first discovery of scale-bearing blennies (Teleostei) in the Sarmatian of Moldavia. Paleontological Journal, 23(2), 59-65.

Bannikov, A. F. (1993). A new species of bass (Teleostei, Moronidae) from the Sarmatian of Moldova. Paleontological Journal, 27(1), $54-62$.

Bannikov, A. F. (2009). On early Sarmatian Fishes from the Eastern Paratethys. Paleontological Journal, 43, 569-573.

Bannikov, A.F. (2010). Fossil vertebrates of Russia and adjacent countries. Fossil Acanthopterygian fishes (Teleostei, Acanthopterygii). Moscow: Russian Academy of Sciences, Borissiak Paleontological Institute, Geos (in Russian), 1-244.

Bannikov, A. F., \& Kotlyar, A. N. (2015). A new genus and species of early Sarmatian porgies (Perciformes, Sparidae) from the Krasnodar Region (in press). Paleontological Journal, 49, 627-635.

Baykina, E. M. (2012). A new clupeid genus (Pisces, Clupeiformes, Clupeidae) from the Sarmatian of the Eastern Paratethys, Krasnodar Region. Paleontological Journal, 46, 302-312.

Baykina, E. M. (2015). A new species of the genus Sardina (Pisces, Clupeidae) from the Missle Miocene of the Eastern Paratethys. Paleontological Journal, 49, 402-406.

Bedini, E., Francalacci, P., \& Landini, W. (1986). I pesci fossili del Miocene superiore di Montefiore conca e Mondaino (Forli). Memorie del Museo civico di storia naturale di Verona, Scienze della Terra, 3, 1-66.

Bogatshov, V.V. (1936). New data on the Transcaucasian Miocene. In: Proceedings of Azerbaijan Scientific-Research Oil Institute, 31, 1-34. (in Russian).

Bratishko, A., Schwarzhans, W., Reichenbacher, B., Vernihorova, Y., Corić, S. (2015). Fish otoliths from the Konkian (Miocene, early Serravallian) of Mangyshlak (Kazakhstan) - testimony of an early endemic evolution in the Eastern Paratethys. Paläontologische Zeitschrift, 89, 839-889.

Brzobohaty, R. (1979). Sparus insignis (Prochazka, 1893) (Pisces, Teleostei) otolity in situ ze svrchniho bádenu Opavska. Casopis Slezského Muzea v Opave, A, 23, 167-177.

Brzobohaty, R. (1992). Otolithen aus dem Obermiozän, Pontien, des Wiener Beckens (Götzendorf und Stixneusiedl, NÖ). Annalen des Naturhistorischen Museums in Wien, 94, 1-6.

Brzobohaty, R. (1994). Die Fischotolithen des Badenien von Gainfarn, Niederöstereich (Mittelmiozän, Wiener Becken). Annalen des Naturhistorischen Museums in Wien, 96A, 67-93.

Brzobohaty, R., Reichenbacher, B., \& Gregorova, R. (2003). Teleostei (Otoliths, skeletons with otoliths in situ) from the Karpatian of the Central Paratethys. In R. Brzobohaty, I. Cicha, M. Kovac, \& F. Rögl (Eds.), The Larpatian, a lower Miocene stage of the central paratethys (pp. 265-279). Brno: Masaryk University.

Brzobohaty, R., Stancu, J. (1974). Die Fishfauna des Sarmatien s. str. In: Papp, A., Marinescu, F., Senes, J. (eds.), M5. Sarmatien. Die sarmatische Schichtengruppe und ihr Stratotypus. Chronostratigraphie und Neostratotypen. Miozän der zentralen Paratethys, 4, 492-515.

Carnevale, G., Bannikov, A. F., Landini, W., \& Sorbini, C. (2006). Volhynian (Early Sarmatian s.l.) fishes from Tsurevsky, North Caucasus (Russia). Journal of Paleontology, 80, 684-699.

Carnevale, G., Haghfarshi, E., Abbasi, S., Alimohammadian, H., \& Reichenbacher, B. (2011). A new species of silverside from the
Late Miocene of NW Iran. Acta Paleontologica Polonica, 56, 749-756.

Chaine, J. (1958). Recherches sur les otolithes des poissons. Etude descriptive et comparative de la sagitta des téléostéens (suite). Bulletin du Centre d'Etudes et de Recherches Scientifiques Biarritz, 2, 141-233.

Fedotov, V. F. (1971). Novyi iskopaemyi rod semeistva treskovych. Paleontologicheskii Zhurnal (in Russian), 3, 121-124.

Fedotov, V. F (1976). Gadidae of the Palaeogene-Neogene from the USSR. Trudy Paleontologicheskogo Instituta, 157, 1-84. [Official English translation of the original Russian version, marked Translation No. 75, by Walter Ivantsoff].

Gabelaia, T. D. (1971). Atherina (Teleostei) iz pliotsena Abkhazii. Paleontologicheskii Zhurnal (in Russian), 2, 130-131.

Gaudant, J. (1979). Cherasco (Piemont): un nouveau gisement de poissons fossiles du Messinien continental d'Italie. Géobios, 12, $113-121$.

Gaudant, J., \& Reichenbacher, B. (2005). Hemitrichas stapfi n.sp. (Teleostei, Atherinidae) with otoliths in situ from the Late Oligocene of the Main Basin. Zitteliana, A45, 189-198.

Gorjanović-Kramberger, D. (1891). Palaeoichthyoložki prilozi II. Rad JAZU (in Croatian), 106, 59-129.

Ionko, V. I. (1954). O nakhodke iskopayemykh ryb v nizhnesarmatskikh otlozheniyakh MSSR. Trudy Odesskogo Universiteta. Sbornik Geologo- Geograficheskogo Fakul'teta (in Russian), 2, 109-119.

Keller, T., Reichenbacher, B., \& Gaudant, J. (2002). Erstbeschreibung von Atheriniden-Skeletten (Pisces, Teleostei, Atheriniformes) mit Otolithen in situ aus den Unteren Hydrobien-Schichten (Wiesbaden Formation) des Mainzer Beckens, mit einem Beitrag zur Sedimentologie und Paläoökologie. Courier Forschungsinstitut Senckenberg, 237, 319-343.

Koken, E. (1891). Neue Untersuchungen an tertiären Fisch-Otolithen II. Zeitschrift der deutschen geologischen Gesellschaft, 43, 77-170.

Lombarte, A., Chic, O., Parisi-Baradad, V., Olivella, R., Piera, J., \& Garcia-Ladona, E. (2006). A web-based environment for shape analysis of fish otoliths. The AFORO database. Scientia Marina, $70,147-152$.

Nelson, J. S. (2006). Fishes of the world (4th ed.). New Jersey: Wiley.

Nolf, D. (1985). Otolithi piscium. handbook of paleoichthyology 10. Stuttgart, New York: Gustav Fischer.

Nolf, D. (2013). The diversity of fish otoliths, past and present. Brussels: Royal Belgian Institute of Natural Sciences.

Nolf, D., de Potter, H., \& Lafond-Grellety, J. (2009). Hommage à Joseph Chaine et Jean Duvergier. Diversité et variabilité des otolithes des poissons. Mortsel: Palaeo Publishing and Library.

Pobedina, V.M. (1956). Spravochnik po mikrofaune sredne- i verkhnemiocenovykh otlozhenii Azerbaidjana. In: Pobedina. V.M., Voroshilova, A.G., Rybina, O.I., Kuznetsova, Z.V. (eds.). Baku: Azerbaidjanskoe gosudarstvennoe izdatelstvo neftyanoi nauchno-tekhnicheskoy literatury (in Russian), 1-191.

Reichenbacher, B. (2000). Das brackisch-lakustrine Oligozän und Unter-Miozän im Mainzer Becken und Hanauer Becken: Fischfaunen, Paläoökologie, Biostratigraphie, Paläogeographie. Courier Forschungsinstitut Senckenberg, 222, 1-143.

Rückert-Ülkümen, N. (1996). Weitere Beiträge zur Otolithenfauna von Avcılar W Küçükçekmece See (Thrakien, Türkei). Mitteilungen der Bayerischen Staatssammlung für Paläontologie und Historische Geologie, 36, 117-133.

Rückert-Ülkümen, N., \& Kaya, O. (1993). Neue Beiträge zur TertiärStratigraphie und Otolithenfauna der Umgebung von Istanbul (Küçükçekmece- und Büyükçekmece See), Türkei. Mitteilungen der Bayerischen Staatssammlung für Paläontologie und Historische Geologie, 33, 51-89. 
Schubert, R. J. (1906). Die Fischotolithen des österr.-ungar. Tertiärs III. Jahrbuch der kaiserlich-königlichen geologischen Reichsanstalt, 56, 623-706.

Schultz, O. (2013). Catalogus Fossilium Austriae (Vol. 3). Pisces. Wien: Verlag der Österreichischen Akademie der Wissenschaften.

Schwarzhans, W. (1978). Otolith-morphology and its usage for higher systematical units, with special reference to the Myctophiformes s.1. Mededelingen Werkgroep Tertiaire en Kwartaire Geologie, 15, 167-185.

Schwarzhans, W. (2013). A comparative morphological study of the Recent otoliths of the genera Diaphus, Idiolychnus and Lobianchia (Myctophidae). Palaeo Ichthyologica, 13, 41-82.

Schwarzhans, W. (2014). Synonymisation of the skeleton-based Palimphemus anceps Kner, 1862 and the otolith-based Colliolus sculptus (Koken, 1891) (Pisces, Teleostei, Gadidae). Cainozoic Research, 14, 9-16.
Switchenska, A. A. (1959). Iskopaemij predstavitelj semejstva Mullidae. Materialy $k$ Osnovam paleontologii (in Russian), 3, 117-118.

Switchenska, A. A. (1973). Fossil mugiliforms of the USSR. Trudy Paleontologičeskogo Instituta Akademii Nauk SSSR (in Russian), 138, 1-64.

Switchenska, A.A. (1980). Otryad Mugiliformes. In: Novitskaya, L.I. (ed.): Iskopaemye kostistye ryby SSSR. Trudy Paleontologičeskogo Instituta Akademii Nauk SSSR (in Russian), $178 C, 104-114$.

Sytchevskaya, E. K., \& Prokofiev, A. M. (2007). A dragonet (Perciformes: Callionymidae) from the Middle Miocene of southern Russia. Voprosy Ikhtiologii, 47, 750-756.

Weiler, W. (1942). Die Otolithen des rheinischen und nordwestdeutschen Tertiärs. Abhandlungen Reichsamt Bodenforschung, $N F, 206,1-140$. 